\title{
Importance of Information and Communications Technology (ICT) in Balance Sheet Categories Training
}

\author{
Ph.D. Alfio Barbieri \\ Full professor, Faculty of economy and tourism, Juraj Dobrila University of Pula, Croatia \\ Email: abarb@unipu.hr \\ Ph.D. Nevenka Tatković \\ Full professor, Faculty of Educational Sciences, Juraj Dobrila University of Pula, Croatia \\ ntatkovic85@gmail.com \\ Elena Barbieri \\ MA. of Business Informatic \\ elena.barbieri@outlook.com
}

Doi:10.5901/mjss.2015.v6n2s5p347

\begin{abstract}
The paper discusses and examines the importance of information and communication technologies (ICT) in the contexts of balance sheet categories training. In the contemporary education ICT has an important role. It is the most widely spread technology of the modern age which represents the basis for economy and knowledge society in the 21 st century. The society should accept the challenge of new technologies, creating new knowledge as the most important supporting pillars of the knowledge society. The promotion of a knowledge society requires radical changes of the school system in general, and a new concept of school as a 'learning community'. Implementation of ICT are positively associated with increased productivity in the learning process and better performance of educational tasks. Therefore the educational institutions should be flexible, adapt to new changes, constantly learn and introduce innovations. The introduction of ICT to the accounting courses teaching process allow professors and students to have adequate access to all accounting and balance sheet categories, such as resources, liabilities, equity, income and expenses, and understanding of the inter-correspondent relationships in the preparation of accounting balance system equations and balance sheet categories flow based on the equilibrium state of main groups of balance sheet categories. This will make students become adequately equipped with the competences they will need on the labor market.
\end{abstract}

Keywords: information and communication technologies (ICT), balance sheet accounting categories, knowledge society, "learning community', competences for the labor market.

\section{Introduction}

The term Information and Communications Technologies implies the technologies used for handling information. This, for example, includes technologies for data storage (magnetic and optical media, semiconductor memory, etc. ), technologies for data transmission (radio, television, mobile phones, computer data transmission, etc. ), data processing technologies (computers of all kinds and their external devices), computer programs and services, and computer networks. ICT is, therefore, a term that covers a multitude of technologies designed for handling information, which reflects the fundamental importance and essence of ICT activities. During last thirty years ICT deeply modified subjects and society in their approach to learning and in knowledge construction. The main consequences is a double preliminary analysis on the influence that digital device had on mankind: a former perspective in concerned with the impact of digital technologies on the different learning environments ( constructivist, socio-constructivist and connectives) responsible for individuals' learning: the latter viewpoint is mainly interested in communities, both on learning and of practice, their influence on individuals' learning and their role in organizations ( Cartelli, 2010: 123).

Modern technologies bring about new methods of interaction and communication, and require constant adjustment to the new conditions, as well as a systematic implementation of such changes to all aspects of life and work in order to be in tune with the changes, where computer literacy is becoming a fundamental core which the use of ICTs is based on. 


\section{Information and Communications Technologies (ICT) and Traditional Education}

Information and Communications Technology (ICT)1 is the most widely spread technology of the modern age which represents the basis for economy and society in the 21st century (Tatković, Močinić, 2012). Today, the creation of Europe of Knowledge is a key factor in the development of individuals and the society, and it represents an important component of the 2007)strenghtening of competitiveness and improving the economy, science and European citizenry of the new millenium (Europa 2020 - strateški okvir Europske unije).

"A further development of individuals' competences on all the levels of education is certainly crucial for the promotion of a knowledge society, which requires radical changes of the school system in general, and of the higher education system in particular. "A learning society requires a new concept of school as a 'learning community'. Schools and the entire education system are required to be capable of a quick and efficient adaptation in the changeable globalisation and informatisation conditions, as well as to be able to create mechanisms for a timely and high-quality response to the needs of the "learning society" (Kostović, 2006: 314).

In order to respond to the contemporary constant, variable and turbulent demands of the present-day society, modern ICTs introduce changes and represent a challenge to the classical approach to educating pupils/students (Tatković: 2007). New forms of studying are introduced on the individual, group and institutional levels, collecting information of all sorts, such as knowledge, understanding, the 'know-how', techniques and procedures, to continuously enhance the education system and its achievements and results. Education institutions' ability to teach must be greater and faster than the changes in the environment. Today's generations of pupils / students are growing up in a digital and virtual environment and thus have a need for a different approach to teaching and learning (Tatkovic 2009). Traditional methods of teaching were based on encyclopaedic knowledge, whereas current teaching methods are more flexible because they strive to adapt to the requirements and needs of individual pupils / students, by departing from a predetermined modular study programme curriculum and pre-planned content of individual courses (De Ascaniis, S. 2006, Tatković , 2009). With this new method of personalized teaching by applying new curricula, the individual students, with the help of the teaching media and educational technology, become responsible for their own intellectual progress in their own education, which brings into focus their individual capabilities for research and problem-solving by relying on a variety of research and discovery methods (Foerster, von H. 1991 in: Giaconi, C. 2008). The purpose of contemporary education is to develop competencies for structuring, designing and implementing modern technologies as an additional support in education, as well as for a future personal development and professional work of an individual. Thus, modernday education becomes unrestricted and undetermined by the geographic location (e. g. country, city) and physical space (classrooms, houses).

Technological development and new technologies offer advantages which schools and higher education institutions should maximize in order to become competitive in the knowledge market and to keep pace with the modern times. In today's digital age and technologically developed environment, which becomes increasingly digitized, technologically more developed and evolved with strong developmental prospects for the future, the need arises for new knowledge and skills, such as the following (Tatković, Močinić, 2012, according to Maravić, 2003):

1. Critical thinking;

2. Flexible skills, adaptable to a variety of situations;

3. ICT skills necessary for professional work;

4. Decision-making abilities;

5. Handling dynamic situations;

6. Teamwork;

7. Effective communication.

These skills help prepare the individual for an intense battle on the labor market, where only those who are able to adapt will succeed. If pupils / students have learned and mastered certain skills through interaction with the environment and new technologies, but the educational institution does not know how to take advantage of this particular knowledge, their pupils' / students' potential, or the technology itself, it will fall short of todays's norms and values instead of attaining success. It should be a mutual, interactive relationship in the form of mutual learning. Educational institutions should be flexible, adapt to new ideas and changes, constantly learn and introduce innovations, and promote the development of knowledge and exchange of information, which will make their pupils / students become more educated and adequately equipped with the knowledge they will need on the labor market in the future, so they can play an active role in it. Quick

${ }^{1}$ ICT - abbreviation of the English term Information and Communication Technology - used for both singular and plural (technology / technologies); IKT - Croatian abbreviation of the term Informacijska i komunikacijska tehnologija. 
learning also implies rapid adaptation to the environment which keeps advancing in the technical and technological sense, and this in turn determines the institution's long-term success, continuous improvements, increased creativity and promotion of innovations, thus attracting and retaining people who are willing to learn, thrive and succeed.

\section{The Ompact of Information and Communications Technologies (ICT) on Teaching Activities within the Accounting - Balance Sheet Training}

Competencies of teachers as the main initiators of progress and education as the basis of advancement are the fundamental capital of the modern society and a key factor in the economic development, providing the background and support for a successful use of ICTs, professional advancement and lifelong learning.

If the professors are of high quality, contemporary and familiar with the innovations, they will quickly and effectively deal with a world of constant technological changes, new accounting methods and legal solutions, introducing them successfully into the process of creating and performing their teaching. The professor, as the creator of the teaching process and the person who conducts classes with the use of modern ICT, is not only responsible for, but also essential in a successful implementation and integration of ICTs in the teaching process, where ICT itself is an indispensable element of effective education that encourages innovation, communication and interaction (e. g. interactive exercises) in the teaching process. Therefore, pupils / students should be motivated enough by their faculty teachers to use the available ICT, and thus gain confidence in their use and take advantage of numerous benefits that ICTs can provide to a modern student's education. The use of ICTs in the accounting course teaching process also requires a close familiarity with the content of the accounting courses. The introduction of ICT to the accounting courses teaching process will therefore allow professors and students to have adequate access to all accounting and balance sheet categories, such as resources, liabilities, equity, income and expenses. It will facilitate the presentation and understanding of the intercorrespondent relationships in the preparation of accounting balance system equations and balance sheet categories flow based on the equilibrium state of main groups of balance sheet categories. For this purpose, the following equation of the opening balance will be set:

$$
\begin{aligned}
& A=P \quad \text { (1) } \\
& \mathrm{DI}+\mathrm{KNI}+\mathrm{Nl}=\mathrm{K}+\mathrm{O}_{d}+\mathrm{O}_{\mathrm{K}} \\
& \text { where: }
\end{aligned}
$$

The displayed equation expresses the balance sheet at the beginning of a period - a year. It results in the equality between assets and liabilities in the balance sheet as a whole, and equality between the initial categories of assets and the initial categories of liabilities in the balance sheet. Each balance sheet category can be expressed as a resultant of the other balance sheet categories. With the emergence of an economic process, all the elements are dynamized, changing from the initial balance into a dynamic state. Certain categories increase, and the others decrease, which establishes a continuous equilibrium of the balance sheet. Income and expenses that directly affect the amount of equity and assets emerge in the process. Such a setting is interpreted in the following dynamics equation:

$\mathrm{DI}+(\mathrm{p}-\mathrm{s})+\mathrm{KNI}+(\mathrm{p}-\mathrm{s})+\mathrm{NI}+(\mathrm{p}-\mathrm{s})+\mathrm{T}=\mathrm{K}+(\mathrm{p}-\mathrm{s})+\mathrm{O}_{\mathrm{d}}+(\mathrm{p}-\mathrm{s})+\mathrm{O}_{k}+(\mathrm{p}-\mathrm{s})+\mathrm{P}$

where:

$p=$ relevant category increase $T=$ expenses

$S=$ relevant category decrease $P=$ revenues

This equation includes the balance sheet categories' initial state and all subsequent changes that increase and decrease the related categories in an accounting period. If, at the end of the period, the amount of generated revenues exceeds the expenses incurred, then the profit will be included in the equation:

$\mathrm{DI}+(\mathrm{p}-\mathrm{s})+\mathrm{KNI}+(\mathrm{p}-\mathrm{s})+\mathrm{NI}+(\mathrm{p}-\mathrm{s})=\mathrm{K}+(\mathrm{p}-\mathrm{s})+\mathrm{O}_{\mathrm{d}}+(\mathrm{p}-\mathrm{s})+\mathrm{O}_{\mathrm{k}}+(\mathrm{p}-\mathrm{s})+\mathrm{D}$

where:

$D=$ profit

which also represents the value of the balance sheet at the end of the period. By abstracting or by including profits into the amount of equity, the following situation will occur at the end of the period:

$\mathrm{Dl}+(\mathrm{p}-\mathrm{s})+\mathrm{KNI}+(\mathrm{p}-\mathrm{s})+\mathrm{Nl}+(\mathrm{p}-\mathrm{s})=\mathrm{K}+(\mathrm{p}-\mathrm{s})+\mathrm{O}_{\mathrm{d}}+(\mathrm{p}-\mathrm{s})+\mathrm{O}_{\mathrm{k}}+(\mathrm{p}-\mathrm{s})$

If we want to show the state of one balance sheet category at the end of the period by using the state of other balance sheet categories, then we will isolate the desired category to the left side of the equation, and place all other 
balance sheet categories to the right side. This will be shown as follows:

$\mathrm{DI}+(\mathrm{p}-\mathrm{s})=\mathrm{K}+(\mathrm{p}-\mathrm{s})+\mathrm{O}_{\mathrm{d}}+(\mathrm{p}-\mathrm{s})+\mathrm{O}_{\mathrm{k}}+(\mathrm{p}-\mathrm{s})-\mathrm{KNI}+(\mathrm{p}-\mathrm{s})-\mathrm{NI}+(\mathrm{p}-\mathrm{s})$

$\mathrm{KNI}+(\mathrm{p}-\mathrm{s})=\mathrm{K}+(\mathrm{p}-\mathrm{s})+\mathrm{O}_{\mathrm{d}}+(\mathrm{p}-\mathrm{s})+\mathrm{O}_{\mathrm{k}}+(\mathrm{p}-\mathrm{s})-\mathrm{DI}+(\mathrm{p}-\mathrm{s})-\mathrm{NI}+(\mathrm{p}-\mathrm{s})$

$\mathrm{NI}+(\mathrm{p}-\mathrm{s})=\mathrm{K}+(\mathrm{p}-\mathrm{s})+\mathrm{O}_{\mathrm{d}}+(\mathrm{p}-\mathrm{s})+\mathrm{O}_{\mathrm{k}}+(\mathrm{p}-\mathrm{s})-\mathrm{DI}+(\mathrm{p}-\mathrm{s})-\mathrm{KNI}+(\mathrm{p}-\mathrm{s})$

An increase in one type of assets corresponds to a decrease in other types of assets, with an increase in capital, and with an increase in liabilities. A decrease in one type of assets corresponds to an increase in other types of assets and the reduction of capital and liabilities.

With the above mentioned groups of balance sheet categories equations, we have determined that the individual balance sheet categories of assets positively affect the balance sheet categories of liabilities, and negatively affect the remaining balance sheet categories of assets. We will show the category of balance sheet liabilities as follows:

$\mathrm{K}+(\mathrm{p}-\mathrm{s})=\mathrm{DI}+(\mathrm{p}-\mathrm{s})+\mathrm{KNI}+(\mathrm{p}-\mathrm{s})+\mathrm{NI}+(\mathrm{p}-\mathrm{s})-\mathrm{O}_{\mathrm{d}}+(\mathrm{p}-\mathrm{s})-\mathrm{O}_{\mathrm{k}}+(\mathrm{p}-\mathrm{s})$

Increase in equity corresponded to the increase in assets and with the reduction in liability. Conversely, reducing equity corresponds with a decrease in assets and an increase in liabilities.

$\mathrm{O}_{d}+(\mathrm{p}-\mathrm{s})=\mathrm{DI}+(\mathrm{p}-\mathrm{s})+\mathrm{KNI}+(\mathrm{p}-\mathrm{s})+\mathrm{NI}+(\mathrm{p}-\mathrm{s})-\mathrm{K}+(\mathrm{p}-\mathrm{s})-\mathrm{O}_{\mathrm{k}}+(\mathrm{p}-\mathrm{s})$

Increase in long term liabilities corresponds to the increase in assets, with a decrease in equity and a decrease in current liabilities. Conversely, a decrease in liabilities corresponds with a decrease in assets, an increase in equity and an increase in current liabilities.

$\mathrm{O}_{k}+(\mathrm{p}-\mathrm{s})=\mathrm{DI}+(\mathrm{p}-\mathrm{s})+\mathrm{KNI}+(\mathrm{p}-\mathrm{s})+\mathrm{NI}+(\mathrm{p}-\mathrm{s})-\mathrm{K}+(\mathrm{p}-\mathrm{s})-\mathrm{O}_{\mathrm{d}}+(\mathrm{p}-\mathrm{s})$

Increase in current liabilities corresponds to an increase in assets, a reduction of equity and a reduction of long term liabilities. Conversely, a decrease in current liabilities corresponds with a decrease in assets, an increase in equity and an increase in long term liabilities.

If any of the so far presented balance sheet categories determine a difference between debit and credit transactions in a given period, or if we subsctract the opening balance from the end period balance, we will get the increase of the respective category, which can be either positive or negative $(p-s=D)$, depending on whether the debit or credit turnover of the respective balance sheet category was higher, and whether the respective category belongs to the assets or liabilities side of the balance sheet. Namely, a positive difference between debit and credit transactions of the assets balance sheet category and a positive difference between credit and debit transactions of the passive balance sheet categories represents a positive increment. Conversely, a negative difference between debit and credit transactions of the assets balance sheet category and a negative difference between credit and debit transactions of the passive balance sheet categories represents a negative increment. We determine the difference between the final and the initial balance, i. e.:

$$
\begin{aligned}
& \text { final balance } \quad \mathrm{Dl}_{1}+\mathrm{KNl}_{1}+\mathrm{Nl}_{1}=\mathrm{K}_{1}+\mathrm{O}_{\mathrm{d} 1}+\mathrm{O}_{\mathrm{k} 1} \\
& \text { - opening balance } \mathrm{DI}+\mathrm{KNI}+\mathrm{NI}=\mathrm{K}+\mathrm{O}_{d}+\mathrm{O}_{\mathrm{K}} \\
& =\text { balance sheet } \\
& \text { category increase } \mathrm{DI}+\mathrm{KNI}+\mathrm{NI}=\mathrm{K}+\mathrm{O}_{d}+\mathrm{O}_{k} \\
& \text { where: } \\
& 1=\text { indicates the final balance of the respective category } \\
& =\text { increase in the respective category }
\end{aligned}
$$

In that sense we got an equilibrium state for the increase in balance sheet categories, and all balance sheet categories recorded positive increment. In reality, individual balance sheet categories show a positive increment while others show a negative increment.

The use of ICT in training for accounting balance sheet categories can be viewed from various perspectives. First of all, the ICTs themselves can be the topic of study. In fact, prior to any application in the teaching process, a student should master them, learn about their functionality and possible implementation, with particular emphasis on their use within the accounting balance sheet categories framework. This means that the very use of ICT must be a learning topic. ICT can be used as a tool within the teaching process for the presentation of balance sheet categories when calculating the correspondent relations and projecting future conditions and processes. Finally, ICT can be used as a means of testing, communication, research, etc.

A Professor / teacher should be competent in using ICTs and computers as supporting tools for teaching classes, and for different intended teaching purposes, to ensure the achievement of optimal technical, pedagogical, professional and working conditions in the educational process. By using ICT in education, pupils / students become active and disciplined participants, thus making teaching itself more effective.

Apart from professors / teachers, the management structure of an education institution also plays an important role in the implementation of ICT and innovations in this field. They should also be aware of the major role, various 
possibilities and the pedagogical advantages of using modern technologies to ensure material resources for their acquisition and didactical use and its subsequent operational use, which is also based on new methods of teaching in accordance to the times we live in.

Computer and IT knowledge, skills and competencies, and the curriculum for professor/teacher training, as crucial factors of participation in ICT-based education, have a cause-and-effect relationship with the computer and IT education, as well as with achievements of pupils / students, and of all those who participate in the education process. In order to achieve a successful application of ICTs in teaching and professional development, teachers / educators at all levels of education have to continuously improve their competencies which are required for the application of ICTs, and improve their pedagogical and methodological / didactic competencies in order to carry out their tasks effectively in today's technological environment.

The introduction of ICT in the teaching process should be regular, systematic and direct, subordinated to and in line with specific goals and a variety of learning contexts, along with the modification of the existing sources, while developing new educational contexts and choosing the working environment and working conditions appropriate to different groups of pupils / students.

\section{Terms of Application of Information and Communications Technologies (ICT) in Learning Activities within the Education Process}

In these new technological conditions, which are constantly changing, teachers must be trained for the work, which means they need to adapt quickly to new requirements and develop specific communication skills, such as the use of email, tracking chat conversations, moderation of forums, dealing with blogs, etc. , which pupils / students use in order to keep pace with the modern trends.

Three basic requirements could be identified which are necessary for the teachers to successfully apply ICT in the accounting / balance sheet teaching process:

- professor-teacher must be convinced that the use of ICTs will be more effective in the presentation of materials, securely defining the balance sheet accounting categories and establishing inter-correspondent balance-sheet relations;

- the use of ICT will also help to understand other goals of business entities' operations, such as the rationalization of the production process or the application of adequate purchasing policies, etc ;

- $\quad$ all of this is possible if the professor / teacher possesses the necessary competence to use ICT.

Educational experience which a professor / teacher possesses will be appreciated according to the application of $I C T$, oriented torwards the purpose, goals and relationships within the appropriate learning context. It is necessary to continue the analytical research of opportunities provided by the selected application in relation to the balance sheet accounting categories and its possible practical use; to anticipate subsequent training of technical skills; to propose programming and / or adjustment of specific activities (e. g. programming of didactic activities) to verify understanding; to guarantee support and tutorship by colleagues or other professionals in the following stages.

Thus, UNESCO's ICT competency standards for teachers / educators (ICT CST, 2008) provide guidelines for professors / teachers and pupils / students on how to live, learn and work in an extremely complex and rich IT knowledge society, emphasizing the need for an effective use of ICT, where professors / teachers need to posess competence for the organization and implementation of technologically supported learning and stimulating environment. From UNESCO's publications, as well as from the EU documents on ICT and computerization (Digital Agenda for Europe 2010-2020), ${ }^{2}$ emerges the conclusion about an exceptional importance of information literacy and digital competencies development of all European citizens, especially those involved in the teaching process (teachers, professors), for a successful work and life in Europe as a knowledge society.

The present time is characterized by the reign of technology. Technology is becoming increasingly more contemporary. It rapidly becomes obsolete, and continuously requires new knowledge, skills and competences, so that individuals and the whole society could quickly adapt to the ever growing demands of new technologies and thus ensure

\footnotetext{
2 The Digital Agenda for Europe establishes seven priority areas of action at EU level, among which an important one is improving digital literacy, knowledge and e-inclusion. Other priority areas of the Digital Agenda for Europe are the following: creation of a single digital market, improving the interoperability of information and communication products and services, fostering trust and security on the Internet, ensuring the provision of much faster internet access, encouraging investment in research and development, improvement of digital literacy, knowledge and e-inclusion and the application of information and communication technologies in addressing key challenges of society, such as climate change, increasing health care costs and aging population.
} 
progress and wealth of the nation (Ghisla, G. 2006).

With the help of modern ICTs, the field of education and other areas of social life can be managed, further increasing the high quality of education process and the quality of knowledge.

\section{Conclusion}

The quality of modern knowledge has far surpassed traditional encyclopedic learning at schools, replacing it, with the help of ICTs, with new knowledge, which is based on logical reasoning, pupils' / students' creativity and mutual expansion and exchange of knowledge. A high degree of interactivity and adaptability is required at all levels of the education system, which contributes to a quicker and more efficient education. In fact, in this way, knowledge is adopted more quickly, thus achieving higher productivity and expanding education and knowledge, modernizing and improving it with new contents, methods and forms of work at all levels of education, thus ensuring integration into modern teaching trends (Gerlič, I. 2010).

In order to significantly improve and enhance education and increase the quality of the education process in the form of teaching and learning at all levels of education, it is necessary to computerize educational institutions, i. e. to increase financial investments in IT equipment such as hardware and software.

The importance of ICTs in the education quality management is indirectly visible in the following areas (Tatković, Močinić, 2012):

$>$ Selecting the most favorable education options;

> Improvement and effectiveness assessment of the chosen teaching methods and strategies;

$>$ Development of systems and tools to support the education performance;

$>$ Improving methods of monitoring and evaluating the progress of educational projects;

The implementation of the teaching process itself.

\section{References}

Cartelli, A. (2010). Digital Competences in Online Classes. The 9th European Conference on E-Learning: 4-5 November 2010, pp. 123

De Ascaniis, S. (2006). II progetto DeSeCo: Le competenze chiave per la società dell'informazione. In: Quaderno dell'Istituto Comunicazione Istituzionale e Formativa "Competenze e loro valutazione in ambito formativo", n. 12, nov. 2006. Università della Svizzera Italiana. Lugano: Facoltà di Scienze della Formazione.

Europa 2020 - strateški okvir Europske unije. http: //ceahrvatska. wordpress. com/2011/03/15/europa-2020/. (5. 2. 2012).

Foerster, von H. (1991). In: Giaconi, C. (2008). Le vie del costruttivismo. Roma: Armando Editore.

Gapski, H. (2007). Alcune riflessioni sulla Digital Literacy. TD-Tecnologie didattiche, 43, 1: pp. 23-25.

Gerlič, I. (2010). Challenges of Advanced Technologies and School of Future. Organizacija, vol. 43, 1: pp. 49- 53.

Ghisla, G. (2006). La valutazione delle competenze. In: Quaderno dell'Istituto Comunicazione Istituzionale e Formativa "Competenze e loro valutazione in ambito formativo", n. 12, nov. 2006.

Kostović, S. (2009), Kompetencije nastavnika kao dimenzija profesionalnog razvoja nastavnika-pretpostavka pedagoškog menađmenta. In: Evropske dimenzije reforme sistema obrazovanja i vaspitanja, Emil, Kamenov (ed), Novi Sad: Univerzitet u Novom Sadu, Filozofski fakultet, pp 314-319.

Maravić, J. (2003). UNESCOV dokument o informacijskoj i komunikacijskoj tehnologiji u obrazovanju. Edupoint. III, n. 20. http: //edupoint. carnet. hr/casopis/20/clanci. (8. 3. 2011.)

Tatković, N. , Močinić, S. (2012). Učitelj za društvo znanja. Pedagogijske i tehnologijske paradigme bolonjskog procesa. Pula: Sveučilište Jurja Dobrile u Puli

Tatković, N. (2007). Teacher Training College, New Technology and Bologna Process. In: Comparative Education, Teacher Training and New Education Agenda, vol. 5. Sofija: Bureau for Educational Services \& Bulgarian Comparative Education Society: pp. 236-246.

Tatković , N. (2009). Teachers' and Students' ICT Competences in the Context of the Bologna Proces. SoftCOM, 17. International Conference on Software, Telecomunications \& Computer Networks, Sept. 24-26, 2009. Split-Hvar-Korčula (Croatia). 